\author{
Людмила Віталіївна Рябець \\ Інститут української мови \\ Національної академії наук України \\ ORCID: 0000-0003-4829-715X; e-mail: riabetslv@ukr.net
}

\title{
Ідеографічний словник як форма представлення діалектного матеріалу
}

\begin{abstract}
Реферат: У статті окреслено етапи становлення ідеографічної діалектної лексикографії в українському мовознавстві, теоретичні аспекти випрацювання методики їх укладання. Наголошено на важливості наукової спадщини професора М.В. Никончука в ділянці створення ідеографічних діалектних словників; його досвід $є$ цінним для дослідників, які прагнуть повно відтворити лексику діалектів. Подано огляд опублікованих праць, виконаних за ідеографічною методикою. Відзначено, що представлення діалектного лексичного матеріалу у формі ідеографічного словника розширює межі традиційного діалектного тлумачного словника і максимально зберігає всю зафіксовану в говірках мовну інформацію.
\end{abstract}

Ключові слова: діалектна лексикографія, диференційний словник, ідеографія, ідеографічний діалектний словник, тематичний словник, семантичні зв'язки

\begin{abstract}
An ideographic dictionary as a form of dialectal material presentation. The article outlines the main stages of emergence of ideographic dialectal dictionaries in Ukrainian linguistics, the theoretical aspects of working out the method of compilation thereof. Emphasis has been placed on the importance of professor M.V. Nykonchuk's scholarly legacy in the area of compiling ideographic dictionaries based on dialectal material. His experience is extremely valuable for researchers who make attempts at fixing and presenting recorded lexical material as much as it is possible. The article provides a brief overview of dialectal works published in the previous decades. According to the author, presentation of dialectal lexical material in the form of an ideographic dictionary allows to expand the scope of a traditional, interpretive dialectal dictionary and to preserve all the recorded information.
\end{abstract}

Keywords: dialectal lexicography, differential dictionary, ideography, ideographic dialectal dictionary, thematic dictionary, semantic relations

Друга половина XX - початок XXI ст. позначений активним розвитком української діалектної лексикографії. Розширення емпіричного підгрунтя діалектології актуалізувало фіксування лексичних одиниць у лексикографічних працях різних типів. Як зазначає П.Ю. Гриценко, „Поняття діалектний словник сьогодні об'єднує праці, які суттєво відрізняються своїми засадами. Ці відмінності можуть стосуватися: а) кола носіїв діалекту, чиє мовлення репрезентоване у словнику (словник ідіолекту - одного діалектоносія...; говірки; групи говірок; наріччя; діалектної мови); б) наявності чи відсутності обмежень у репрезентації лексики 
говірок. Репрезентація усієї записаної в говірках лексики відносить такий словник до типу повного словника; при цьому повний словник не означає вичерпний, а лише такий, за межі якого не виведено елементи, спільні з лексикою літературного ідіому" (Гриценко 2005, 13). Українська діалектна лексикографія дуже різноманітна; на тлі словників диференційного тлумачного типу виділяються словники етнолінгвістичні, діалектно-етнографічні, фразеологічні, епідигматичні тощо; особлива група лексиконів - ідеографічні діалектні словники.

Ідеографію визначають як „напрям лексикографії, що тематично впорядковує лексикон мови й подає його у словниках-тезаурусах" (Селіванова 2006, 172-173). Українська, як, власне, і світова, ідеографія „започаткувала напрямок комплексного вивчення історії мовомислення, зосередженого навколо втілення ідей певних часових періодів та словесного відтворення архетипів культури. Укладачі ідеографічних словників показали переваги систематизування словесного матеріалу навколо смислових домінант (ідей, понять, концептів, архетипів) в окресленні шляхів пізнання світу людиною" (Сніжко 2016, 41). Мовознавці розглядають ідеографічний словник „крізь призму картини світу, яка у свідомості будь-якого носія мови $є$ абсолютно тотожною до його середовища та мовного вираження" (Демчик $2013,51)$. Так, наприклад, читач першого тому „Ідеографічного словника болгарської мови” (ИДРБЕ), який охоплює невелику частину лексики (літери А - Д), «отримує цілком адекватне уявлення про змістове багатство всього лексикону, до того ж не лише у власне лексичному, а й в етнокультурному плані” (Толстая 2013, 199), оскільки джерелами ИДРБЕ послужили опубліковані словникові матеріали, етнографічні описи, записи багаторічних діалектологічних експедицій, архівні матеріали (список джерел налічує близько ста позицій).

Загалом ідея тематичного (або як його ще називають - ідеографічного, ідеологічного, систематичного) словника не нова. Ідеографічна лексикографія має багату традицію в зарубіжному мовознавстві. Варто згадати праці П.М. Роже, Е. Блана, П. Буасьєра, Х. Касареса, Ю.М. Караулова, В.В. Морковкіна, О.С. Баранова, Н.Ю. Шведової та ін. Заслуговує на увагу досвід болгарських мовознавців Ст. Стойкова, М. Младенова, Т. Бояджиєва та ін. у створенні ідеографічних словників, зокрема діалектних.

У колективній монографії „Украинский семантический словарь. Проспект” (УСС) представлено огляд наукових праць з теорії та практики ідеографії, зокрема наголошено на важливості дослідження структури синоптичних схем ідеографічних словників задля вибору методики побудови тезауруса.

В основу побудови ідеографічних словників покладено лексико-семантичні о3наки та смислові відношення слів мовної системи. Звичною $є$ алфавітна побудова словника, але ,алфавітний принцип, при всій його зручності й універсальності, не дає змоги продемонструвати системність лексики. ... автори тлумачних алфавітних словників за допомогою посилань відтворюють деякі лексичні зв'язки. Однак алфавіт все-таки розриває семантично споріднені слова” (Середницька 2007, 266).

Ідеографічний словник має ономасіологічне спрямування: від понять до слів. Його реєстровими одиницями $є$ поняття, кожному 3 яких підпорядкована словникова стаття - множина слів, які виражають це поняття в мові. 
I. Сабадош зауважує: „У тематичних словниках відображені результати пізнання людиною об'єктивного світу, а також відношення між лексичними одиницями мови: родо-видові, синонімічні, антонімічні та ін. Ці словники бувають універсальні, тобто такі, що охоплюють лексику, яка стосується всієї поняттєвої системи ..., і спеціальні, що містять лексику якої-небудь однієї тематичної групи" (Сабадош 2003, 206).

Для створення тематичного словника лексикограф обирає окремий фрагмент дійсності (тему), що членується на окремі сегменти - підтеми, поняття.

Структурно діалектний ідеографічний словник складається з таких основних частин: список обстежених населених пунктів, тематична частина - презентований діалектний матеріал та його індекс (покажчик слів і словосполучень, що містяться в тематичній частині). Матеріали локалізовані відсиланням до окремих населених пунктів, рідше - адміністративних районів, географічних регіонів. До списку пронумерованих населених пунктів нерідко додається ще й карта обстеженої території, на якій зазначені номери відповідних населених пунктів, поданих у списку обстежених населених пунктів (Сабадош 2003, 206-207).

Важливою рисою ідеографічного словника є багатоступеневе розташування слів. Розміщення поряд споріднених за змістом слів у словнику грунтується на списку понять. Словникова стаття може розпочинатися 3 назви поняття, яке наповнене словами, з якими воно може сполучатися в тій чи тій тематичній групі, тобто дається уявлення про семантичне поле цього поняття. Ця стаття є близькою до семантичного поля, а всередині неї виділено синонімічні ряди, антонімічні пари, групи похідних дієслів.

В українській діалектній лексикографії відомий досвід укладання тематичних спеціальних словників. Свого часу I. Зілинський мав задум створити Лінгвістичний атлас Галичини. Зібраний за його питальниками діалектний матеріал згодом опрацював і підготував до друку у вигляді матеріалів тематичного словника „Studia nad dialektologią ukraińską i polską” М. Карась у Ягеллонському університеті (Studia). Структура цієї праці така: подано список назв населених пунктів, власне діалектні матеріали, словник діалектизмів, алфавітний індекс опрацьованих лексем. Уміщено також шість лінгвістичних карт як ілюстрацію тих можливостей, які дає для лінгвістичної географії викладений у праці матеріал.

Популярності в українській діалектології набули праці М.В. Никончука, створені за принципом ідеографічного упорядкування матеріалу. Дослідник усе своє наукове життя дбав про максимальну повноту джерельної бази для досліджень з української діалектології. У цій галузі він знаний передовсім як грунтовний лексиколог, адже переважна більшість праць у його науковому доробку стосується вивчення (фіксації, систематизації, аналізу) лексики, зокрема поліської. Він обстежив близько півтисячі поліських говірок, що охоплюють територію восьми областей трьох країн - України, Білорусі та Росії. За кілька десятиліть польової роботи йому вдалося зібрати велику картотеку поліської лексики. I тоді Перед дослідником гостро постала проблема вибору формату представлення діалектного слова. М.В. Никончук був прихильником лінгвогеографічного методу репрезентації діалектного матеріалу, який вважав максимально інформативним. На жаль, підготовка та друк лінгвістичного атласу 
в той час була справою нелегкою і досить трудомісткою. Дослідник віднайшов доступний спосіб збереження записаної в експедиціях інформації, перевівши зібраний для атласів матеріал у лексикографічний формат, створивши регіональний словник. Безперечно, М.В. Никончук усвідомлював, що таке переформатування діалектного матеріалу дещо зневиразнює його просторові характеристики, ареальні відношення в досліджуваному континуумі. До того ж, традиційний регіональний діалектний словник має багато обмежень і застережень щодо формування реєстру і структури словникових статей. Щоб не втратити бодай одну незначну особливість, для когось, можливо, непримітну деталь, він шукав способу якомога повніше представити увесь зібраний матеріал. Його прагнення зберегти максимально всю здобуту інформацію про кожну номінативну одиницю (формальну структуру, семантику, інколи - особливості функціонування, локалізацію) i, що не менш важливо, - опублікувати працю, удоступнивши матеріали іншим дослідникам, підштовхнуло його до цього незвичного експерименту.

Автор запропонував оригінальне представлення своїх записів - матеріал подати за тематичними групами в алфавітному порядку, даючи точну локалізацію кожного слова. Таких збірників лексики професор М.В. Никончук опублікував п'ять: Матеріали до лексичного атласу украӥнської мови (Правобережне Полісся) (1979), Сільськогосподарська лексика правобережного Полісся (1985), Ендемічна лексика Житомирщини. Методичні рекомендації для вчителів (1989), Будівельна лексика правобережного Полісся в лексико-семантичній системі східнослов'янських мов (1990), Транспортна лексика правобережного Полісся в системі східнослов'янських мов (1990; три останні - у співавторстві з О.М. Никончуком). Про працю Матеріали до лексичного атласу української мови (правобережне Полісся) С.М. Толстая зазначила, що це не традиційний діалектний словник, до якого ми звикли, але й не атлас, бо тут немає лінгвістичних карт, та зміст праці дозволяє визнати іiі тим і тим одночасно (Толстая 1982, 350). Публікація Mатеріалів до лексичного атласу украӥнської мови (Правобережне Полісся) ,розірвала зачароване коло неможливості представлення географії лексики і семантики з орієнтацією на картографічний формат чи його аналог. Практика показала, що запропонований М.В. Никончуком прийом презентації матеріалу виявився оптимальним щодо точності відтворення структурних і семантичних особливостей кожної номінативної одиниці (зрідка - навіть 3 наведенням мінімальних контекстів слововживання) та географії явищ” (Гриценко 2005, 27).

Сам автор по-різному визначав жанр своїх праць, зауваживши у вступі до книги „Транспортна лексика правобережного Полісся в системі східнослов’янських мов”, що „у світ випускається нова лексико-тематична монографія із серії поліського словництва, присвячена транспортній лексиці”, а відрізняється від попередніх праць тим, що подає „лексико-семантичний фактаж не лише 3 правобережнополіського діалекту, доповнений лексико-семантичними даними із суміжних територій української та білоруської мов, а охоплює весь відомий авторам ономасіологічний матеріал тематичної групи транспорту східнослов'янських мов” (Никончук 1990, 3).

Порівняймо інформативність традиційного діалектного словника диференційного типу, наприклад, „Словника поліських говорів” П.С. Лисенка (Лисенко 1974) 
3 представленням матеріалу в оригінальних працях М. Никончука. Наприклад, словникову статтю батіг 'прикріплений до держака мотузок або ремінець, яким поганяють тварин’ у книзі „Транспортна лексика правобережного Полісся в системі східнослов'янських мов» подано так: відповідно до генетичного принципу вміщено назви цієї реалії: пуга, батіг і низка фонетичних варіантів (батиг, баmіх, бакіх, баті та ін.), бич, посвіст, поцяг, джукла, кнут, малахай, карбач, бізун, бікур, байч, канчук (Никончук 1990, 174). Усі лексеми паспортизовано. Допомагає в пошукові потрібної лексеми покажчик слів у кінці книги. Формат традиційного словника не дозволяє подати всього семантичного і лексичного розмаїття говору. Не всі лексеми потрапляють до реєстру, ареалогію лексеми і генетичне гніздо за словником теж відтворити складно. Відповідно, у „Словнику поліських говорів” П. Лисенка вокабули батіг не знаходимо, однак $\epsilon$ стаття пуга з ілюстраціями та локалізацією (Лисенко 1974, 177).

Наскільки повно дають ареалогічну характеристику окремому мовному явищу лінгвістичний атлас та ідеографічний словник, можна побачити на прикладі праць М.В. Никончука „Матеріали до лексичного атласу української мови (Правобережне Полісся)” та „Лексичний атлас Правобережного Полісся”. Так, у „Матеріалах до лексичного атласу української мови (Правобережне Полісся)” у тематичній групі „Рельєф. Водоймища” сему 'місце, де починається річка' представлено так:

„,оча́ток 97, 101, ..., нача́ло 14-21, ..,, нача́ток 276-278, ..,, зача́ток $276-278, \ldots$,

вйтік 293, 378, ...,

край 344, ...

волока́ 129-134, ...,

ури́в ч.р. $232, \ldots$,

верх 98, в'ершо́к 10, 30, варшо́к 84, ..., верх'і́вйа с.р. 411, 423, верхавйе́ 31-35, ..., верхо́вина 453, в'ерхави́шче с.p. 4-6, вершина́ 420, верши́на 304, ..., вери'іна $178, \ldots$,

голови́шче с.p. 384-386,

горлови́на $\underline{339}, \ldots$,

б'épaz 9, 10, 30 (p'éчка в'ixód’im'з б'е́рага 10),

г'ірло́ с.p. $\underline{108}, \ldots$,

русло́ с.p. $1,143, \ldots$,

болиічатка 235, ...,

крин'ічнойе ме́сто 44, 45, ..., кр'ін'ічов'іна 100, 102, ...” (Никончук 1979, 33-34).

Далі в статті зазначено, що в багатьох говірках назва відсутня, у частині говірок інформанти вказують, де починається річка (з доли́ни, з боло́та тощо). Слова подано в транскрипції, є граматичні ремарки - зазначення категорії роду в окремих випадках. У традиційному діалектному словнику такі близькі за значенням лексеми були б розташовані далеко одна від одної, зважаючи на

\footnotetext{
1 Повний перелік номерів населених пунктів не наводимо. Підкреслення населеного пункту передаємо за оригіналом; воно означає, що в статті є повторення: слово має лексичний синонім або в цьому пункті має деривативні, демінутивні чи фонетичні паралелі.
} 
алфавіт. Цьому номену присвячено карту № 10 „Назви для місця, де починається річка” в „Лексичному атласі Правобережного Полісся” (Никончук 1994), на якій скартографовано назви, які найчастіше вживаються в говірках Правобережного Полісся, зокрема: поч’аток, нача́ло, нача́ток, вытокъ, вьрши́на та ін. Усе лексичне розмаїття семи 'місце, де починається річка' представлене в індексі, доданому до карти, яка дає уявлення про географію цієї назви. На карті чітко окреслено ареали, утворені лексемами ури́в, волока́, б’е́раг, головши́че. Як бачимо, ідеографічні словники дають досить широке представлення лексичного матеріалу, а в лінгвістичному атласі не всі лексеми надаються до картографування, хоча суттєво унаочнюють уявлення про територіальне поширення явища.

Розвинуту М.В. Никончуком форму представлення діалектного слова у вигляді ідеографічного словника продовжили діалектологи на матеріалі говірок 3 інших теренів України: І.В. Сабадош, Т.П. Терновська, В.Л. Конобродська, І.В. Гороф’янюк, Г.П. Краєвська, В.М. Бережняк, П.Ф. Романюк.

Діалектні матеріали, підготовлені за такою методикою, були опубліковані в „Українському діалектологічному збірнику. Книга 3. Пам’яті Тетяни Назарової”, зокрема: „Лісосплавна лексика українських говорів Карпат” І. Сабадоша (Сабадош 1997), „Ковальська лексика українських говорів” Т. Терновської (Терновська 1997), „Номінація поліського поховального обряду. I” В. Конобродської (Конобродська 1997) та „Лексика східнополіських гончарів” В. Бережняк (Бережняк 1997). Ці матеріали невеликі за обсягом, але досить інформативні.

I. Сабадош представив лісосплавну лексику (лексику, що пов'язана 3 плотовим лісосплавом, і лексику, що відбиває сплав лісу розсипом), зібрану ним у 19701971 рр. у 84 населених пунктах Львівської, Івано-Франківської, Закарпатської та Чернівецької областей. У межах мікрогруп лексика розміщена за реалемним принципом. До публікації додано картосхему мережі обстежених говірок та список обстежених населених пунктів.

T. Терновська подала матеріали, зібрані в спеціальних експедиціях у різних українських діалектних зонах у 1972-1977 рр. у 260 населених пунктах (карту мережі додано) за спеціально укладеною ілюстрованою програмою (Програма).

В. Конобродська репрезентувала матеріали про поліський поховальний обряд, зібраний упродовж 1982-1992 рр. за мережею Поліського етнолінгвістичного атласу (Сборник). До мережі обстеження увійшли українські й білоруські говірки. Питальник, за яким записано матеріал, охоплює понад 200 питань, „частина 3 яких спрямована на вияв власне номінативної сторони обряду, а частина - на фіксацію акціональної, предметної, ритуальної сторін” (Конобродська 1997, 428). До публікації додано карту мережі обстежених говірок та список обстежених населених пунктів.

В. Бережняк представила матеріал, зібраний у східнополіських гончарних центрах упродовж 1990-1995 років за спеціальною програмою, що охоплювала 250 питань. Авторка зауважила, що навіть у досі знаних гончарних центрах, які продовжують функціонувати, багато реалій не збереглося, втрачено назви значної кількості спеціальних термінів.

Логічним продовженням серії українських публікацій за методикою М.В. Никончука є праці „Ботанічна лексика центральноподільських говірок: Матеріали до 
Лексичного атласу української мови” І.В. Гороф’янюк (2012) та „Народновиробнича термінологія центральноподільських говірок: Матеріали до Лексичного атласу української мови” Г.П. Краєвської (2018).

У цих працях, на відміну від попередніх, уміщено лінгвістичні карти, чим підтверджено заявлену в назві тезу, що це „матеріали до Лексичного атласу української мови".

Зокрема, І.В. Гороф'янюк представила записані у 2006-2008 роках у 94 населених пунктах Вінницької обл. флорономени; записи зроблено за спеціальним питальником, укладеним свого часу О.А. Малахівською. У питальнику 1305 позицій, а корпус зафіксованих флорономенів центральноподільських говірок налічує 5500 номінативних одиниць (без урахування фонетичних та акцентних варіантів). Представлена ботанічна лексика „презентує тематичну групу як складне структурне ціле, що об'єднує назви сільськогосподарських культур, плодових і ягідних рослин, родові / видові назви, назви різновидів і сортів, морфологічних частин рослин, назви площ, на яких ростуть або росли рослини, назви етапів онтогенезу сільськогосподарських культур, назви виробів з рослинної сировини" (Гороф’янюк, 9), тобто охоплено поняття, що виходять за межі власне рослинного світу. Авторка подала 40 лінгвістичних карт для зіставлення з тематично відповідними картами „Атласу української мови” та „Атласу ботанічної лексики української мови” І.В. Сабадоша. Структурно (і для зручності користувачів) у книзі, окрім власне матеріалів, подано мережу обстежених населених пунктів, словопокажчик назв, реєстр лінгвістичних карт та список інформантів.

Г.П. Краєвська об’єктом дослідження обрала термінологію традиційних народних ремесел. Матеріал авторка записала за спеціальним питальником (1113 питань, що мають підпункти), побудованим за тематичним принципом, де представлено лексику теслярства, столярства, стельмаства, бондарства, ковальства, плетіння і каменярства. Як і в праці I.В. Гороф'янюк, питальником охоплено чимало понять, що виходять за межі народних ремесел, зокрема, окрім назв ремесел, представлено назви майстрів, їхніх помічників; найближчого родинного оточення; місця, де працює майстер; назв інструментів та процесів; видів матеріалу; виробів та їх частин. Реєстр цього тематичного словника становить 635 словникових статей. У ньому представлено акцентуаційні, фонетичні, словотвірні, лексичні, граматичні варіанти. У праці вміщено 14 лінгвістичних карт, а також карту обстежених населених пунктів та 7 карт, які репрезентують поширення подільських традиційних народних ремесел. Окрім власне словникової частини та карт, у книзі Г.П. Краєвської представлено 40 текстів спонтанного діалектного мовлення, тематика яких не виходить за межі сфери традиційних народних ремесел i в яких респонденти пояснюють та коментують окремі номени. Маніфестовано також 70 фразеологізмів, у яких закарбувалася лексика, пов'язана 3 аналізованими ремеслами. Важливо, що в книзі подано програму-питальник, за яким зібрано матеріал. $€$ також довідкова інформація: індекс аналізованих лексем та мережа обстежених населених пунктів.

Згадані вище ідеографічні словники засвідчують пошуки діалектологами форм і методів представлення діалектного матеріалу, які задовольняли б прагнення дослідників діалектного мовлення точно відтворити зібраний матеріал. Аналізовані 
ідеографічні словники, де матеріал уміщено за принципом від значення до слова, де семеми об'єднано в лексико-тематичні групи, дають підстави стверджувати, що такий формат упорядкування та експлікації діалектного матеріалу дає можливість ширше показати ареалогію побутування лексеми та іiі фонетичних варіантів, представити зв'язки між лексемами. Реєстри таких праць часто значно ширші, порівняно з традиційними словниками. I хоча тривалий час діалектологи вважали диференційний принцип побудови діалектологічних словників найбільш економним i раціональним, однак спроби представити діалектний матеріал в іншому форматі засвідчили перспективність інших методів. Отже, українська діалектна лексикографія на початку XXI століття розвивається традиційно із використанням уже випробуваних попередниками та залученням новітніх методик, і $є$ цінним надбанням для всієї славістики.

\section{Література}

Бережняк В. (1997), Лексика східнополіських гончарів [Berezhniak V., Leksyka skhidnopoliskikh honchariv], [в:] Український діалектологічний збірник: Книга 3. Пам'яті Тетяни Назарової [Ukrainskyi dialektolohichnyi zbirnyk: Kniha 3. Pamiati Tetiany Nazarovoi], Київ, с. 459-468

Гороф'янюк I.В. (2012), Ботанічна лексика иентральноподільських говірок: Матеріали до Лексичного атласу української мови [Horofianiuk I.V., Botanichna leksyka tsentralnopodilskykh hovirok: Materialy do Leksychnoho atlasu ukrainskoi movy], Вінниця.

Гриценко П.Ю. (2005), Українська діалектна лексика: реальність і опис (деякі аспекти) [Hrytsenko P.Yu., Ukrainska dialektna leksyka: realnist $i$ opys [deiaki aspekty]], [в:] Діалектна лексика: лексикологічний, лексикографічний та лінгвогеографічний аспекти. Матеріали доповідей Міжнародної наукової конференщіï [Dialektna leksyka: leksykolohichnyi, leksykohrafichnyi ta linhvoheohrafichnyi aspekty. Materialy dopovidi Mizhnarodnoi naukovoi konferentsii], Глухів, с. 5-33.

Гриценко П.Ю. (2007), Осягнення слова: професор Микола Васильович Никончук [Hrytsenko P.Yu., Osiahnienia slova: profesor Mykola Vesiliovich Nykonchuk], [в] Професор Микола Васильович Никончук: Матеріали до бібліографії вчених, упоряд. і авт. вступ. ст. П.Ю. Гриценко, [Profesor Mykola Vesiliovich Nykonchuk: Materialy do bibliografii vchenykh, uporiad. I avt. vstup. st. P.Yu. Hrytsenko], Київ, с. 3-47.

Демчик І.Л. (2013), Діалектний ідеографічний словник: особливості укладання та побудови [Demchyk I.L., Dialektnyi ideohrafichnyi slovnyk: osoblyvosti ukladannie ta pobudovy], „Science and Education a New Dimension: Philology”, I(2), Issue 11, Nov., c. 51-55

ИДРБЕ, Идеографски диалектен речник на българския език, гл. ред. В. Радева [Ideografski dialekten rechnik na blgarskiia ezyk, gl. red. V. Radeva], т. 1: А-Д (А-D), София, 2012.

Конобродська В. (1997), Номінація поліського поховального обряду [Konobrodska V., Nominatsiia poliskoho pokhovalnoho obiadu], I, [в:] Украӥнський діалектологічний збірник [Ukrainskyi dialektolohichnyi zbirnyk], кн. 3: Пам'яті Тетяни Назарової (Pamiati Tetiany Nazarovoi), Київ, с. 428-458.

Лисенко П.С. (1974), Словник поліських говорів [Lysenko P.S., Slovnyk poliskykh hovoriv], Київ. 
Никончук М.В. (1979), Матеріали до Лексичного атласу украӥнської мови [Правобережне Полісся) [Nykonchuk M.V., Materialy do Leksychnoho atlasu ukrinskoi movy [Pravoberezhne Polissia]], Київ.

Никончук M.В. (1985), Сільськогосподарська лексика Правобережного Полісся [Nykonchuk M.V., Silskohospodarska leksyka Pravoberezhnoho Polissia] Київ.

Никончук М.В. (1994), Лексичний атлас Правобережного Полісся [Nykonchuk M.V., Leksychnyi atlas Pravoberezhnoho Polissia], Київ.

Никончук М.В., Никончук О.М. (1990а), Будівельна лексика правобережного Полісся в лексико-семантичній системі східнослов'янських мов [Nykonchuk M.V., Nykonchuk O.M., Budivelna leksyka Pravoberezhnoho Polissia $v$ leksyko-semantychnii sistemi skhidnosovianskikh mov], Житомир.

Никончук М.В., Никончук О.М. (1989), Ендемічна лексика Житомирщини (Nykonchuk M.V., Nykonchuk O.M., Endemichna leksyka Zhitomirshchyny), Житомир.

Никончук М.В., Никончук О.М. (1990б), Транспортна лексика правобережного Полісся в системі східнослов'янських мов (Nykonchuk M.V., Nykonchuk O.M., Transportnaia leksyka pravoberezhnoho Polissia v sistemi skhidnosovianskikh mov), Київ.

Програма, Шарпило Б.А., Терновська Т.П. (1973), Програма збирання матеріалів для вивчення лексики металооброблення в украӥнській мові [Sharpilo B.A., Ternovska T.P., Prohrama zbyrannia materialiv dlia vuvchennia leksyku metaloobrablennia $v$ ukrainskii movi], Ворошиловград.

Сабадош I. (2003), Зведений тематичний словник як вид лексикографічної праиі ]Sabadosh I., Zvedenyi tematycheskyi slovnyk yak vid leksykohrafichnoi pratsi], [в:] ВолиньЖитомирщина: Історико-філологічний збірник з регіональних проблем [VolinZhytomirshchyna: Istoryko-filolohichnyi zbirnyk z rehionalnych problem], № 10, Житомир, c. 206-211

Сабадош І.В. (1997), Лісосплавна лексика українських говорів Карпат. Украӥнський діалектологічний збірник [Sabadosh I., Lisosplavna leksyka ukrainskykh hovoriv Karpat. Ukrainskyi dialektolohichnyi zbirnyk], кн. 3: Пам'яті Тетяни Назарової [Pamiati Tetiany Nazarovoi], Київ, с. 343-398.

Сборник, Полесский этнолингвистический сборник [Polesskii etnolingvisticheskii sbornik], Москва, 1983.

Селіванова О. (2006), Сучасна лінгвістика: термінологічна енциклопедія [Selivanova O., Suchasna linhvistyka: terminolohichna entsyklopediia], Полтава.

Середницька А. (2007), Ідеографічні словники та перспективи їхнього використання (на матеріалі ідеографічного словника дієслів переміщення сучасної української мови) [Serednitska A., Ideohrafichni slovnyki ta perspektyvy ikhnoho vykoristannia [na materiali ideohrafichnoho slovnyka dieslivperemishchennia suchasnoi ukrainskoi movy]], [в:] Teоpiя i практика викладання украӥнської мови як іноземної [Teoria i praktyka vikladannia ykrainskoi movy yak inozemnoi], вип. 2, с. 266-271.

Сніжко Н. (2016), Украӥнська ідеографія: історія, сучасний стан та перспективи, „Українська мова” [Snizhko N., Ukrainska ideohrafiia: istoriia, suchasnyi stan ta perspektyvy, „Ukrainska mova”] № 3, c. 28-43.

Терновська Т. (1997), Ковальська лексика украӥнських говорів [Ternovska T., Kovalska leksyka ukraińskich hovoriv], [в:] Украӥнський діалектологічний збірник [Ukrainskyi dialektolohichnyi zbirnyk), Книга 3. Пам’яті Тетяни Назарової (Pamiati Tetiany Nazarovoi], Київ, с. 399-427. 
Толстая С.М. (2013), [Рец.:] Идеографски диалектен речник на българския език, гл. ред. В. Радева, т. 1: A-Д. София: Български бестселър - Национален музей на българската книга и полиграфия, 2012, 1055 с. [Tolstaia S.M., [Rets.] Ideografski dialekten rechnik na blgarskiia ezyk, gl. red. V. Radeva, t. I: A-D, Sofia: Blgarski bestsel'r - Natsionalen muzei na blgarskata kniga i poligrafiia, 1055 s.], „Rocznik Slawistyczny”, t. LXII, c. 197-205.

Толстая C.M. (1982), Об одном опыте ареального исследования полесской лексики [Тolstaia S.M., Ob odnom opyte arealnego issledovanija polesskoi leksiki], [в:] Общеславянский лингвистический атлас. Материаль и исследования. 1980 ]Obshcheslavianskii lingvisticheskii atlas. Materialy i issledovanija. 1980], Москва, с. 350-360.

УСС, Пещак М.М., Клименко Н.Ф., Карпиловская Е.А., Украинский семантический словарь. Проспект [Peshchak M.M., Klymenko N.F., Karpilovskaia E.A., Ukrainskyi semantycheskyi slovar. Prospekt], Киев, 1990.

Studia, Studia nad dialektologia ukrainska i polska (z materiałów b. Katedry języków ruskich UJ), opracował i przygotował do druku M. Karaś, „Zeszyty Naukowe Uniwersytetu Jagiellońskiego. Prace Językoznawcze” 1975, z. 44. 